\title{
Occurrence and Understanding of the Issues of Bullying in Primary Schools in Banska Bystrica
}

\author{
Veronika Buvalová Poláková \\ Faculty of Economic and Social Sciences, Comenius University, Slovak Republic
}

Copyright $\mathrm{O} 2018$ by authors, all rights reserved. Authors agree that this article remains permanently open access under the terms of the Creative Commons Attribution License 4.0 International License

\begin{abstract}
Bullying is a very serious social-pathological problem. It is a form of aggression which is often encountered in particular in the school environment, whether at elementary of high schools. At present bullying is not only associated with puberty, but also is a problem among pupils of younger age. The aim of this research was to create and test a reliable research tool to determine what children perceive as bullying, what their direct experience with bullying is and where they most often encounter bullying. Another aim was to determine who should deal with the occurrence of bullying in school. The sampling $(\mathrm{N}=1147$; return $\mathrm{n}=913)$ consisted of pupils from 10 elementary schools Banska Bystrica, Slovakia (from grades 6 to 9, 60 classes together). The questionnaire contained 5 questions requiring open-ended and direct answers. From the first three questions we learned what children perceive as bullying, what forms of bullying they have encountered and in what types of places children have encountered bullying most often. Questions 4 and 5 were focused on intervention and prevention of bullying. The study will include output from the first three questions.
\end{abstract}

Keywords Bullying, Social-pathological Problems, Aggression, Violence, School, Prevention

\section{Bullying Is a Social-pathological Problem}

A violent video bullying appeared on the internet a year ago. The video clearly shows how one of the aggressors pulled out the victims from the mobile phone and the battle started. The helpless girl in crying shouts and screams of pain. The attacker pulls his victim over his hair and gets fed up with him. They kill their victim in the face and body, pulling it like a handkerchief. The girl finally pulls her hair out of the wall to the grass where she kicks her face again.
This is one of the cases of bullying in Slovakia.

In our research we are focusing on bullying in schools. When we have asked pupils in school to define bullying, they said that bullying occurs to them when one is doing other things that do not like him and that he is uncomfortable. Aggressive behavior among children is a common problem nowadays. This includes aggressive behavior in the family environment as well as in school and on the playground. It is important to know how to distinguish individual signs of aggression from repeated signs of aggression. If signs of aggressive behavior appear repeatedly and are focused on one child or certain children, then they constitute bullying. It is without a doubt important to observe the differences between different signs and concentrations of bullying. This is true whether it involves confrontational interaction between two children or situations when an individual attacks a group or a group attacks an individual. Bullying has almost always been considered a problem that occurs in schools only rarely. Kyraciou [1] states that however current research has shown that bullying in schools is more widespread than has been assumed and that the harm that can be caused to the victims can be very serious and can have a long-term character. Bullying to this day is not clearly defined. There are multiple characteristics of this social-pathological problem. According to Roland [2], bullying involves long-term violence, physical and psychological abuse committed by an individual or group against an individual who is in capable of defending himself in such situation. Mellor [2] defined the act of bullying as something that occurs when one person or group tries to impugn the integrity of another person by constantly saying offensive and hurtful things. Sometimes this involves fights or kicking or forcing victims to hand over money. The person who is bullied does not know how to stop what is happening and he comes concerned that it can happen again. We are not referring to bullying involving two people of approximately the same strength.

Each of the affirmation to definitions is of course correct because they all have things in common. However, 
frequency is important. Olweus [3] emphasized that bullying occurs repeatedly and over a certain time period, unlike occasional manifestations of aggression, with the aim of emphasizing the systematic character of bullying. And he also emphasizes that bullying occurs in relationships in which there is asymmetrical division of power. Division of power may draw attention in physical or mental abilities or may involve disproportionate numbers of weaker and stronger individuals. This is true since bullying often occurs without provocation and Olweus considers it a form of abuse. He believes that a victim of bullying is someone who is subjected to negative treatment repeatedly, such as attacks from one or more other students. Those who most often become victims are isolated, sensitive or shyer students who have less self-confidence and to have great difficulty fitting into a collective. Emmer [4] states that risk groups of children also include those who suffer from physical and/or mental disabilities as well as other children with significant differences (such as more obese children etc.). However, children who provoke and irritate other children, for example when they excel at something, can also become victims.

\section{Forms of Bullying}

There are many forms of bullying, and it depends on the point of view from which we recognize this negative phenomenon. We most often differentiate physical, psychological and mixed forms of bullying as well as the new and modern form known as cyber bullying, which is a specific form of psychological bullying. Škorvánková [5] states that in elementary schools we most often encounter direct bullying, such as insulting remarks addressed to a specific child, provoking remarks, rude jokes, demeaning or instructions from other children as well as chasing, poking, punching, kicking, which though not necessarily strong cannot be sufficiently reacted to buy victims. We can also include in this category fights in which one of the participants is weaker and tries to run away. We can understand indirect bullying as exclusion of a child from a collective and spreading of untruthful negative rumors.

However often personal and psychological attacks against the children can be much more painful than physical attacks and can have devastating consequences because they influence further social functioning of the individual in a negative way.

Hamranová [6] in her publication refers to the following types of bullying:

(a) physical violence - poking, hitting, kicking, hitting with an object etc.)

(b) verbal attacks - Involving use of insults, insulting remarks, demeaning

(c) causing of material damage - Taking money, property, damaging items and clothing etc.

(d) social manipulation - isolation, ignoring, exclusion from a group (e) getting on the victim's nerves, threats and intimidation

(f) Coercion, telling the victim what to do

Bullying in any form is criminal behavior in many cases. However, teachers and parents often do not perceive it as such due to insufficient awareness about the problem. However, According to Závodský [6], bullying may constitute:

- The criminal offense of restricting personal freedom

- The criminal offense of extortion

- The criminal offense of theft

- The criminal offense of rape and the criminal offense of sexual abuse

- The criminal offense of assault

- The criminal offense of damage to others' property

However, forms of bullying that constitute criminal offenses are not limited to physical and psychological forms of bullying. Bullying constitutes a serious breach of human rights.

\section{Bullying in the School Environment}

A school fulfills many roles in society and one of them is development of students. In this spirit it is necessary to pay increased attention to the problem of bullying and in particular to its consequences. The longer the social-pathological problem lasts, the more serious its consequences will be. However, by implementing various preventive measures we can prevent bullying from occurring According to Methodical Directive No. 7/2006-R on prevention and tackling of bullying of students in schools and school facilities [7] "We can understand bullying as any type of behavior by one or more students intended to harm one or more other students or behavior that threatens or intimidates them. This includes targeted and repeated use of violence against such student or group of students, which for various reasons either do not know how or are unable to defend themselves." Bullying has various causes. Since our research focuses on elementary schools theoretically we can clarify the causes related to school.

\section{Causes Related to School as a System}

In this category we can include school as a whole, teachers (personalities), developmental and educational approaches, the degree of tolerance of aggression and other factors. Kováčová [8] states, "An unfavorable climate with long-lasting aggression, indifference from teachers, insufficient communication and the lack of interest in the problems experienced by students have a negative effect on relationships in classrooms and can lead to development of bullying when the willingness to deal with the initial signs by education staff in a hostile school environment is 
lacking." The development of bullying is developed to a certain extent also due to the education approaches and styles of teachers and the ways in which they show their authority to students. An environment with hostile behavior is formed among students in the classroom also in situations when a teacher ignores signs of abuse, or does not immediately deal with such behavior among children or even supports such behavior simply to become more popular among the children.

\section{Causes Related to the School Classroom as a System}

We can include among these causes mainly of forming collective in the classroom, development and dynamics of relationships between students affecting the climate in the classroom and its characteristics. Bullying in the classroom often occurs because relationships are disharmonious, there is in difference in the collective as well as unwillingness to help others, the inability of teachers to intervene in conflicts between students that are already taking root. In classrooms in which bullying occurs, separation of students who are stronger from those who are weaker can result in a relationship between such groups which is long-term, becomes increasingly more problematic and changes into a relationship involving dependence between a victim and an aggressor.

\section{Research and Methodology}

The aim of this research was to create and test a reliable research tool to determine what children perceive as bullying, what their direct experience with bullying is and where they most often encounter bullying. Another aim was to determine who should deal with the occurrence of bullying in school. Multiple studies exist in which the results of research into bullying have been interpreted (for example Thornberg). The questionnaire method was used. The questionnaires that have been used in research focus in particular on the occurrence of bullying, forms of bullying as well as the intensity of bullying and the places where bullying occurs most often. However, the results have mostly been analyzed via an arithmetic average, which distorts the results to an extent that interferes with the reflection of the data, and therefore the responses are not analyzed individually. The contents of the questionnaire were inspired by research conducted by PhDr. Katarína Bradová [9] entitled "Bullying in the 2nd grade of elementary schools in the Banska Bystrica Region"

\section{Methodology}

We conducted the research using the questionnaire method. The questionnaire consisted of 5 questions (figure 1).

Please answer a few questions. The research is anonymous, so please do not write your name anywhere.

Gender

$$
\text { Boy Girl }
$$

1) What do you consider to be bullying?

$\begin{array}{lcc}\text { 1a) When someone laughs at me } & \mathrm{O} & \mathrm{O} \\ & \text { Yes } & \text { No } \\ \text { 1b) When someone takes my property } & \mathrm{O} & \mathrm{O} \\ & \text { Yes } & \text { No }\end{array}$

1b) When someone pushes me to the ground $O$

Yes No

1b) When someone hits me

$\begin{array}{cc}O & O \\ \text { Yes } & \text { No }\end{array}$

\section{2) Have you encountered or seen:}

2a) Insults, ridicule, threatening

2b) Kicking, poking, punching

2c) Mean emails, chats, status updates

\section{$\begin{array}{ccccc}0 & 0 & 0 & 0 & 0 \\ \text { Very often } & \text { Often } & \text { Occasionally } & \text { Seldom } & \text { Never }\end{array}$}

Very often Often Occasionally Seldom Never

Very often Often Occasionally Seldom Never 
3) Where have you encountered bullying?
3a) In the locker room
$\begin{array}{ccccc}0 & 0 & 0 & 0 & 0 \\ \text { Very often } & \text { Often } & \text { Occasionally } & \text { Seldom } & \text { Never }\end{array}$
3b) In the classroom
3c) In the hall during breaks
$\begin{array}{ccccc}0 & 0 & 0 & \bigcirc & 0 \\ \text { Very often } & \text { Often } & \text { Occasionally } & \text { Seldom } & \text { Never }\end{array}$
3d) In the restroom
Very often Often Occasionally Seldom Never
3e) In front of the school
$\begin{array}{ccccc}0 & \bigcirc & 0 & 0 & 0 \\ \text { Very often } & \text { Often } & \text { Occasionally } & \text { Seldom } & \text { Never }\end{array}$
$\begin{array}{ccccc}0 & 0 & 0 & 0 & 0 \\ \text { Very often } & \text { Often } & \text { Occasionally } & \text { Seldom } & \text { Never }\end{array}$

4) Who would you say if someone bully you?
4a) To mother or father
Always Probably yes Maybe Probably no Never
4b) To teacher
Always Probably yes Maybe Probably no Never
4c) To friend
Always Probably yes Maybe Probably no Never

5) Who do you think should solve such situations at school?
5a) Class teacher
Always Probably yes Maybe Probably no Never
5b) Educational consultant
$\begin{array}{ccccc}0 & 0 & 0 & 0 & 0 \\ \text { Always } & \text { Probably yes } & \text { Maybe } & \text { Probably no } & \text { Never }\end{array}$
5c) Psychologist
Always Probably yes Maybe Probably no Never
5d) Social pedagogist
$\begin{array}{ccccc}0 & 0 & 0 & 0 & 0 \\ \text { Always } & \text { Probably yes } & \text { Maybe } & \text { Probably no } & \text { Never }\end{array}$

Figure 1. Questionnaire

Types of items in the questionnaire:

- Dichotomic: (simple answer) - yes - no

- Scaling: (selection from 5 values)

-Very often - often - occasionally - seldom - never

During the analysis of the data, multi-level models were used. Multi-level models (sometimes referred to also as hierarchic models or mixed effects models) are based on the expectation of certain groupings in data. Another explanation is that there is an unachieved expectation of error independence: classic regressive models assume that errors are mutually independent - one response is not dependent in a certain way (predictable) on another response. These types of models are referred to as multilevel or hierarchic models because they can have different numbers and types of random factors. In our case we collected data regarding students. Students are grouped in classes (level 1), classes are grouped in schools (level 2), and schools can be grouped in seats of learning (level 3). In this case there is something in common with the traditional "nested" structure: each class belongs to one school, one municipality and one region, and they do not overlap.

\section{Results and Analysis of Data}

Following analysis of all of the data we reached the following results:

As is apparent, many children do not consider "taking things" to be a form of bullying, and a significant number of respondents do not consider physical attack or laughing at someone to be bullying either. However, a large majority of the respondents consider hitting to be a form of bullying. 
There are various forms of bullying, yes, but children understand in different ways what is still amusing for them and when the boundary has been crossed, when attacks in any form are really involved. During the process of finding out whether children had encountered bullying, we used 3 questions with the possible responses very often/ often/ sometimes/ seldom/ never.

\begin{tabular}{|c|c|c|}
\hline Items & yes & no \\
\hline When someone laughs at me & $66 \%$ & $34 \%$ \\
\hline When someone takes my property & $60 \%$ & $40 \%$ \\
\hline When someone pushes me to the ground & $72 \%$ & $28 \%$ \\
\hline When someone hits me & $92 \%$ & $8 \%$ \\
\hline
\end{tabular}

Figure 2. Proportion of responses to questions "What do you consider to be bullying?"

\begin{tabular}{|c|c|c|c|c|c|}
\hline Items & Very often & Often & Sometimes & Seldom & Never \\
\hline Insults, ridicule, threatening & $15 \%$ & $20 \%$ & $33 \%$ & $23 \%$ & $9 \%$ \\
\hline Kicking, poking, punching & $9 \%$ & $15 \%$ & $24 \%$ & $35 \%$ & $17 \%$ \\
\hline Mean emails, chats & $5 \%$ & $7 \%$ & $16 \%$ & $28 \%$ & $45 \%$ \\
\hline
\end{tabular}

Figure 3. Proportion of responses to questions Have you encountered or seen...:

As is apparent, a significant number of children have encountered bullying especially in its direct verbal form ( $35 \%$ of children very often or often) or in its direct physical form (24\% very often or often, another $24 \%$ sometimes).

However, cyber bullying is less widespread: up to $73 \%$ of children have encountered it seldom or never.

During the process of finding out where children had encountered bullying most often, we used 5 questions with the possible responses very often/ often/ sometimes/ seldom/ never.

\begin{tabular}{|c|c|c|c|c|c|}
\hline Items & Very often & Often & Sometimes & Seldom & Never \\
\hline In the locker room & $3 \%$ & $5 \%$ & $13 \%$ & $24 \%$ & $56 \%$ \\
\hline In the classroom & $7 \%$ & $13 \%$ & $22 \%$ & $30 \%$ & $28 \%$ \\
\hline In the hall during breaks & $4 \%$ & $6 \%$ & $17 \%$ & $26 \%$ & $48 \%$ \\
\hline In the restroom & $2 \%$ & $4 \%$ & $7 \%$ & $17 \%$ & $71 \%$ \\
\hline In front of the school & $6 \%$ & $9 \%$ & $19 \%$ & $26 \%$ & $40 \%$ \\
\hline
\end{tabular}

Figure 4. Proportion of responses to questions "Where have you encountered bullying"

As is apparent, children most often encounter bullying in the classroom and least often in the restroom. In front of the school and in the hall during breaks, bullying occurs more frequently than in the locker room, although less often than in the classroom.

\section{Future Research}

For our future research, it is relevant to examine the social contexts which have an influence on the occurrence of bullying. One of the social contexts is the socioeconomic status of the family from which the children originate.
Class is a social group in which a certain hierarchy is prevalent. There are students who can be more dominant as well as weaker individuals in "lower" groups. Children's places on the ladder in this hierarchy may be influenced by the socioeconomic status of the family from which the children come.

Socioeconomic status is often understood as a combination of education, income and employment. Ordinarily it is understood as a social position or class or layer in which an individual or group is categorized. This is relevant for all studies of behavior and social science, including research, experience and education. Lawson et al. [9] states that researchers most often combine income, education and professional position into a composed index of socioeconomic status. Other researchers are intrigued by insufficient perfect correlation among various factors, such as the possibility that differing aspects of socioeconomic status can play various roles in the production of life results, and therefore it is necessary to examine independently various economic and social factors.

The status of a family often even has an effect on the satisfaction of the needs of the child. Children from such families for example do not wear brand-name clothing or brand-name shoes or do not have the newest phones, because their parents cannot afford it. A collective, individual or group may also consider a child to be "weird" or "a looser". And a child may become the target of ridicule also due to their appearance, because they do not conform to the collective. However, this is not a condition. Therefore, we consider it appropriate in further research to examine this area and phenomenon to determine how much of an effect it has on the selection of a victim. The possibility cannot be ruled out that children from poorer families or children living with a single parent are more at risk, because children from incomplete families with low socioeconomic status have parents who are unable to provide the material resources necessary for full development of their children's experiences, and they are often unable to devote time to them to show verbal and emotional sensitivity.

Another area on which our future research will focus involves gender differences in the context of bullying. Since the occurrence of bullying is strongly related to which class a child attends, it is relevant also to examine the contents of a social group. Besides socioeconomic status, it is also necessary to examine gender differences. Some research has shown that girls experience aggression more than boys. Despite its omnipresence in the everyday lives of children, a dispute or conflict is often downplayed for evaluation of female social organization. Maltz \& Borker [10] states that girls are portrayed as inclusive and according Maccoby [10] "cooperative and equal". In sharp contrast to the paradigm which suggests that women are socialized to be less prone to conflict, Goodwin's ethnographic work [10], sociological studies of friendship among girls, recent studies of girls in psychological 
literature, as well as recent evaluation of aggression among girls for the general public have discussed forms of a girl "alternative" or "relay aggression". This phenomenon Crick \& Grotpeter [10] defined as "targeted breaches of friendship or acceptance with the aim of harming another". Behavior related to relay aggression according Simmons [10] includes for example "punishing someone by ignoring them or using negative body language or facial expressions or sabotaging someone's relationship or threatening to end friendship of the affected person does not agree to the other's demands". At variance with the popular belief that direct verbal aggression is more common among boys than among girls, the recent work of Rigby [10] claims that only minor differences between the genders have been discovered. Major differences between genders related to forms of social exclusion were found in studies of Cairns et al. [10] These studies monitored 695 young people during periods of maturity (ages 9-17) in North Carolina. Cairns and Cairns [10] discovered that among girls there were more reported cases of social exclusion and ostracism in early puberty

Verbal and physical attacks are more common among boys than among girls. The position of men in society has been examined by P. Bourdieu [11]. According to him, the main aim of social theory was to clear up the process through which social structures are perceived as objective in the socialization process. Bourdieu's multi-level understanding of the sociological explanation and the attention he devoted to the issues related to how to apply this style of the explanatory breakdown between individual physical and psychological structures and macro-levels of social structures has not been used enough so far. If we focus specifically on the male gender and the acquired prestige according to Bourdieu [11], a characteristic of the male gender is that "masculinity needs other men in order for them to truly appreciate the nature of actual or potential violence and to confirm that they belong to the group of 'real men".

\section{Conclusions}

Bullying at elementary schools is currently a serious problem. The aim of this study was to illustrate the issue of bullying and through research to determine the current situation at elementary schools in Banská Bystrica. We have found that students of selected schools perceive as bullying, especially physical attacks. However, less than half of respondents encountered physical bullying. In contrast, Slovak attacks have occurred more frequently in schools. However, we do not always consider insult or ridicule for bullying. They must include long and repeated attacks. Another finding was that bullying occurs mainly in places with poor educational background, for example, before school, on the way to school or in the halls during breaks. The contrast of these findings is that bullying often occurs in the classroom and involves a closed social group that has its own hierarchical layout and its own rules. For our future research, it will be important to examine the social contexts that can impact bullying directly in a particular class (social status, colleagues, popularity, etc.). In the meantime, this research has been conducted in a particular class but its results have not yet been processed. From the available data, however, it is now possible to state that the pressure of colleagues and popularity are significant factors in bullying, and that the boys perceive bullying, especially physical attacks, and girls, as well as bullying, if they are insulted, scoffed or ignored.

\section{REFERENCES}

[1] KYRIACOU, CH., Řešení výchovných problémů ve škole. Praha: Portál. 2005. ISBN 80-7178-945-3

[2] LINES, D. (2007). The Bullies: Understanding Bullies and Bullying. 2007, Jessica Kingsley Publishers, London UK, s. 224 ISBN - 13: 978-1-84310-578-7

[3] SCHOTT M. R., SONDERGAARD D. M. (2008). New Perspectives on Bullying. Cambridge University Press : Clays UK s. 480 ISBN 978-1-107-02776-3

[4] EMMEROVÁ, I., Aktuálne otázky prevencie problémového správania u žiakov v školskom prostredí. Banská Bystrica: 2011, 150 s. ISBN 978-80-554-0212-4 2

[5] ŠKORVÁNKOVÁ, 2014. Formy a prevencia šikanovania. In. zsrabca [online]. 2014, [cit. 2015-12-03]. Dostupné na internete:

http://zsrabca.edupage.sk/blog2/?jwid=jw1\&bid=blog2\&wi d=jw1_comp_HBox_0_BlogModule_0\&g=comp_HBox_0 B BlogModule_0\&bid $\overline{\mathrm{d}} \overline{\mathrm{b}} \log 2 \&$ aid $=8$

[6] KALISKÁ, L., 2003, Násilie v rodine a škole - monografia štúdií a príspevkov $\mathrm{z}$ odborného seminára, Nitra: UKF, 2003 s. 132 ISBN 80-8050-611-6

[7] Metodické usmernenie č. 7/2006-R z 28. marca 2006 k prevencii a riešeniu šikanovania žiakov $\mathrm{v}$ školách a školských zariadeniach

[8] LACHYTOVÁ, L., 2011, Sociálna patológia, Prešov : ISM, 2011, s.132 ISBN 978-80-893-72-33-1

[9] BRADOVÁ, K., 2012, Bullying in the 2nd grade of elementary schools in the Banska Bystrica Region, Prevencia n. 2, vol. 2012

[10] LAWSON, M. G., HOOK, J. C., HACKMAN, D. A., FARAH, M. J., 2005, Socioeconomic Status and Neurocognitive Development: Executive Function: Neurodevelopment, and Translational Research. In. American Psychological Association Press s. 1-28

[11] GOODWIN, M. H. (2002). Exclusion in girls' peer groups: ethnographic analysis of language practices on the playground. In. Human Development 45: 392-415.

[12] BOURDIEU, P., 2000. Nadvláda mužov, UK : Praha 2000, s. 145 ISBN 80-7184-775-5 